\title{
The Japanese People and Islam
}

\author{
Matsuyama (Mujahid) Yohei*
}

This viewpoint focuses on the main causes and the structure in which many Japanese people misunderstand Islam. I will explain this by illustrating the misunderstandings of Islam among two important actors who convey the information about Islam to the people in Japan; the Japanese Muslims and the non-Muslim intellectuals.

\section{The Ignorance of Japanese Muslims Themselves About Islam}

One of the biggest obstacles for comprehension of Islam in Japan is the lack of comprehension of Islam among the Japanese Muslims themselves. I will refer to two examples.

Firstly, I would like to refer to a book titled To Be a Japanese Muslim which is written by Mr Higuchi, the ex-chairperson of the Japan Muslim Association and a leading figure for da wah in Japan. ${ }^{1}$ In a section of this book, Mr Higuchi describes the six pillars of $\bar{i} m \bar{a} n$. In this section, he gives an account of the meaning and significance of angels (malä'ikah) in Islam. He states: "The angels are very important in our faith of Islam. That is because without angels, our devotions cannot be known by God or reach to God. Angels are the mediators between us and God."2 This rather shocking explanation is clearly inconsistent with the creed of Islam. Allah is al-Khabìr, the All-Knowing, thus He knows everything about us before the angels inform Him. The author is not a 'rank-and-file' Muslim but the ex-chairperson of the biggest association in Japan managed by Japanese Muslims, and he is considered as one of the model Japanese Muslims by many people in Japan. As this example shows, it is very doubtful whether all Japanese Muslims are informed properly and believe in the Islamic creed, the 'aq ' ' $i d$, in an acceptable way.

The second example is the only Japanese imām in Tokyo, the Japanese capital, Shaykh Abdullah Taqi. He has been inaugurated as the Imam of Masjid al-Ikhlās, which is located in the district of Kabukicho, in the very centre of Tokyo. He leads the jum 'ah congregational prayer every Friday, delivering his sermon in Japanese. At first, this appears to be a very good thing. However, I learned that he has never visited an Islamic country, has never studied sharī'ah nor 'aqā'id, and does not even know the ahkām except how to make the jum 'ah prayer. Shaykh Abdullah is privately a very friendly, good-natured and kind-hearted person, but I got the

* Matsuyama (Mujahid) Yohei is currently a Research Fellow at the Japan Society for the Promotion of Science, the Graduate School of Tokyo University of Foreign Studies. 
impression that he does not know even the basic rules of șalāt (obligatory prayers). Apparently, nobody has ever taught them to him. Shaykh Abdullah Taqi happens to be the only Japanese imām in all Tokyo, the capital of Japan. He also has non-Muslim students and is teaching them what Islam is.

Nobody denies that it is inconceivable for non-Muslims in Japan to understand Islam through Japanese Muslims correctly when the eminent Muslims in Japan themselves have no idea about Islam and its creed.

\section{The Intellectuals' Misunderstanding of Islam}

The intellectuals in Japan who specialise in Islamic studies - most of them being non-Muslims - also do not have sufficient comprehension of Islam. Almost all publications dealing with Islam in Japan have been written by them because people want to know Islam from the 'neutral' perspective. This means that much distorted information about Islam is being conveyed to the Japanese readers by those individuals. Iwanami's Glossary of Islam is generally regarded as the most accurate handbook of Islamic studies in Japan. ${ }^{3}$ However, from the perspective of the religion of Islam, its contents are not trustworthy at all. For example, the items which explain key terms such as shaytān (devil) show how low the 'highest-level' of Japanese Islamic study actually is. This glossary describes the devil or shaytān as 'originally angels' and says that he is 'the Fallen Angel'. ${ }^{4}$ These expressions are entirely erroneous, because Muslims - except for a few mystics in the Middle Ages - seem to agree that the devils, including Iblīs, are evil jinns and not angels. Thus the Japanese 'highest-level' glossary cannot confer proper information about Islam even when it comes to the very basic issues such as devils and angels. Dr Izuka Masato is no doubt one of the most prominent scholars in the Islamic studies field in Japan. In one of his writings he gives a commentary on the background of the September 11 terror attacks on the United States and the thoughts of Islamic militants. He mentions that the disappearance of bodies of Muslims who were embroiled and killed in the terror attack is one of the biggest problems for Islamic militants to perform martyrdom attacks. He states that "according to the Islamic creed, the embalming of bodies is very important and indispensable for Muslims on the Day of Judgment. Someone who has lost his body can neither be revived nor enter Paradise. The only exception to this are the martyrs. It is said that they are allowed to enter the Paradise directly even if they lack their bodies." 5 This is a total misapprehension of the Islamic creed. Allah is al-Khäliq, the Creator of everything, and the smashing of bodies does not prevent Him creating them anew on the Day of Judgment.

The above examples show that many intellectuals in Japan lack a proper understanding of Islam in even its fundamental matters, something which we cannot 
consider simply as a divergence of interpretations. Therefore, how in the world could we expect that one will learn Islam from such a 'neutral' position when based on the 'knowledge' of such intellectuals?

\section{The Duty of Muslim Intellectuals: Ghazw Fikrī}

Today, many people in Japan wonder why Islam is so 'difficult to understand'. Some say this is because of the disharmony between the Japanese cosmology of polytheism and Islamic monotheism. Other would argue that that is because of the 'peculiarity' of creed and practice of Islam. However, there seems to be a solid structure which obstructs the way towards a proper understanding of Islam for both those who are sincere in their intention to know Islam from the believers themselves and those who want to know Islam from a 'neutral' position, i.e. from non-Muslim intellectuals. Unfortunately, and as I have tried to demonstrate above, both actors lack the knowledge of even the very basics of Islam.

In closing then, I would like to emphasise here the mission of the Muslim intellectuals in Japan for overcoming this rather unfortunate scenario. Only they would be in the position to transmit to the Japanese people accurate knowledge on Islam - which non-Muslim intellectuals lack. They would be able to combine the academic and 'neutral' narratives which the ordinary Muslims in Japan lack. Only they would be able to embark on ghazw fikrī, a kind of ideological struggle in the academia. They are therefore expected to act as the key player when it comes to impeding islamophobia in Japan by cultivating a profound communication between Islam and Japan and by performing cross-cultural da wah to them.

\section{Notes}

1. M. Higuchi, Nihonjin musurimu toshite ikiru [To Be a Japanese Muslim] (Tokyo: Kouseishuppansha, 2007).

2. Ibid., 34 .

3. K. Otsuka et al. (eds), Iwanami isuramu jiten [Iwanami's Glossary of Islam] (Tokyo: Iwanamishoten, 2002).

4. Ibid., 10 and 445 .

5. M. Izuka, "Isuramu genre shugisya to jibaku tero" [Islamic Fundamentalists and the Suicide Attack], in: K. Nakata, Bin radin no ronri [The Theory of Usama Bin Ladin] (Tokyo, 2002), 215. 